Review

\title{
Prevention of Clostridium difficile Infection and Associated Diarrhea: An Unsolved Problem
}

\author{
Nicola Principi ${ }^{1}$, Margherita Gnocchi ${ }^{2}$, Martina Gagliardi ${ }^{2}$, Alberto Argentiero ${ }^{2}$, \\ Cosimo Neglia ${ }^{2}$ and Susanna Esposito $2, *$ (D) \\ 1 Università degli Studi di Milano, 20122 Milan, Italy; nicola.principi@unimi.it \\ 2 Pediatric Clinic, Pietro Barilla Children's Hospital, University of Parma, 43126 Parma, Italy; \\ margherita.gnocchi@gmail.com (M.G.); marty.gagliardi@hotmail.it (M.G.); alberto.argentiero@unipr.it (A.A.); \\ cosimo.neglia@unipr.it (C.N.) \\ * Correspondence: susanna.esposito@unimi.it; Tel.: +39-0521-704-790
}

Received: 18 August 2020; Accepted: 19 October 2020; Published: 23 October 2020

check for updates

\begin{abstract}
For many years, it has been known that Clostridium difficile (CD) is the primary cause of health-care-associated infectious diarrhea, afflicting approximately $1 \%$ of hospitalized patients. CD may be simply carried or lead to a mild disease, but in a relevant number of patients, it can cause a very severe, potentially fatal, disease. In this narrative review, the present possibilities of CD infection (CDI) prevention will be discussed. Interventions usually recommended for infection control and prevention can be effective in reducing CDI incidence. However, in order to overcome limitations of these measures and reduce the risk of new CDI episodes, novel strategies have been developed. As most of the cases of CDI follow antibiotic use, attempts to rationalize antibiotic prescriptions have been implemented. Moreover, to reconstitute normal gut microbiota composition and suppress CD colonization in patients given antimicrobial drugs, administration of probiotics has been suggested. Finally, active and passive immunization has been studied. Vaccines containing inactivated CD toxins or components of CD spores have been studied. Passive immunization with monoclonal antibodies against CD toxins or the administration of hyperimmune whey derived from colostrum or breast milk from immunized cows has been tried. However, most advanced methods have significant limitations as they cannot prevent colonization and development of primary CDI. Only the availability of vaccines able to face these problems can allow a resolutive approach to the total burden due to this pathogen.
\end{abstract}

Keywords: Clostridium difficile; Clostridium difficile-associated disease; Clostridium difficile infection; diarrhea; vaccines

\section{Introduction}

Clostridium difficile (CD) is a toxin-producing, Gram-positive, spore-forming, anaerobic pathogen that can simply colonize the intestinal tract or be associated with gastrointestinal manifestations of various severity from mild to life threatening that can frequently recur. Severe cases, such as those with pseudomembranous colitis, toxic megacolon, perforation of the colon, and septic shock are diagnosed in about $1 \%$ of hospitalized patients and death can occur in up to $17 \%$ of them, with the highest values during outbreaks [1,2]. According to the European Center for Disease Prevention and Control, CD infection (CDI) is diagnosed when a patient presents with diarrheal stools or toxic megacolon and a positive laboratory assay for CD toxin A and/or B in stools or a toxin-producing CD organism detected in stool via culture or other means e.g., a positive PCR result; or pseudomembranous colitis revealed by lower gastro-intestinal endoscopy; or colonic histopathology characteristic of CDI (with or without diarrhea) on a specimen obtained during endoscopy, colectomy, or autopsy [3]. For many 
years, it has been known that CD is the primary cause of health-care-associated infectious diarrhea, afflicting many hospitalized patients [1]. However, recent studies have shown that CD can also play a relevant role as a cause of disease in the community, as more than $50 \%$ of CDIs have an onset in the community [4]. A study carried out in the USA estimated that in 2011, CD caused just under half a million infections, with approximately 80,000 recurrences and approximately 30,000 deaths [5]. In the EU/EEA, the burden of healthcare-associated CDIs in acute care hospitals it has been estimated at 123,997 cases annually with a number of deaths of about at 3700 [6]. Even higher yearly prevalence of CDI was reported in other studies [7,8] or was calculated by means of mathematical models [9]. In general, studies indicate that both the incidence and severity of CDI have tended to increase, mainly because of the emergence of the highly virulent CD BI/NAP1/027 strain [10]. In the USA, hospital stay for CDI quadrupled between 1993 and 2009 [9], and mortality doubled between 1993 and 2003 [11]. In Europe, in 2008, hospital incidence of CDI was found to be 4.1 cases per 10,000 patient-days, a value almost 70\% higher than that reported in a previous European surveillance study in 2005 ( 2.45 cases per 10,000 patient-days) [12].

Prolonged antibiotic use is the main risk factor for CDI. Other favoring factors are prolonged hospital stay, age $>65$ years, immunosuppression, the presence of severe underlying illness, and the use of antiulcer and chemotherapeutic medications $[13,14]$. Together with medical problems, CD causes substantial economic costs. In a study enrolling a total of 55,504 CDI patients, among whom approximately $25 \%$ had a recurrent episode, it was found that the mean number of hospitalization days was 5.20 days and 1.95 days for primary CD infections and recurrences, respectively. Costs were USD 24,205 for primary infections and USD 10,580 for recurrences [15].

To reduce the total $\mathrm{CD}$ burden, infection prevention has been repeatedly recommended, and several clinical practice guidelines have been developed [16]. Antibiotic stewardship, compliance with CDC, WHO and the European Society of Clinical Microbiology and Infectious Diseases hand-hygiene and contact precaution recommendations, and the use of a sporicidal disinfectant or diluted sodium hypochlorite for environmental cleaning and disinfection are the most commonly recommended strategies to prevent CD infection development and diffusion [17,18]. Moreover, although no guidelines have included them among suggested methods to prevent $C D$ infection and disease, probiotics have been considered by some authors a potential measure in this regard [19]. Finally, attempts to use fecal transplantation [20] and to develop vaccines have been made [21]. In this narrative review, the present possibilities of CDI prevention will be discussed. Studies published in English from January 1990 to May 2020 and indexed in PubMed and Scopus were used. Selection was made using the following key words: $\mathrm{CD}, \mathrm{CDI}, \mathrm{CD}$ diarrhea, $\mathrm{CD}$ prevention, $\mathrm{CD}$ vaccines, probiotics, fecal microbiota transplantation, antibiotic stewardship, and infection control measures.

\section{Infection Control Measures}

As with other bacteria, the skin and environment of a CD-colonized or infected subject become quickly contaminated and are the basis for CDI diffusion among other patients and healthcare professionals. To reduce this risk, all the guidelines for CDI prevention recommend that general infection control measures be systematically applied where potential patients are located $[17,18]$. They include: (1) prompt identification of patients with suspected CDI, (2) the isolation of suspected and documented cases, (3) the disinfection of the patient's room and objects, (4) the use of contact isolation measures such as gloves and gowns, and (5) hand washing.

Early diagnosis of CD carriage or CDI could prevent the spread of the pathogen and the development of recurrences. However, the optimum method of laboratory diagnosis remains controversial. In some cases, a two-step approach beginning with enzyme immunoassays for the detection of glutamate dehydrogenase (GDH) followed by a toxin test and/or a nucleic acid test is recommended. In other cases, a nucleic acid test alone is considered adequate [19]. It is recommended that only patients with unexplained and new onset $\geq 3$ unformed stools in $24 \mathrm{~h}$ must be tested unless an ileus is present. Furthermore, it is highlighted that testing must not be repeated during the same 
episode of diarrhea. Children in the first year of life are excluded due to the high prevalence of asymptomatic carriage in these subjects $[17,18]$. However, whereas the recommendation for children is strong and based on moderate-quality evidence, the one for adults is weak and based on low-quality evidence [16,19]. Patient isolation is generally recommended as is environmental cleaning. The sharing of a room with a patient with CDI has been found to be a risk factor for CDI development [22]. Moreover, environmental cleaning with disinfectants is effective in decreasing patients' risks of developing CDI only in areas where CDI is highly endemic [23,24]. The use of unbuffered 1:10 hypochlorite solution to clean the rooms of patients with CDIAD was found to reduce the incidence rate of the disease for bone marrow transplant patients who previously had an incidence of 8.6 cases per 1000 patient-days to 3.3 cases per 1000 patient-days. In contrast, CDI rates were not reduced among neurosurgical intensive care unit and general medicine patients, for whom rates before intervention were 3.0 and 1.3 cases per 1000 patient-days, respectively [25].

Hand washing with alcohol-based hand rubs or soap and water has been demonstrated to be very effective for the prevention of the transmission of several infectious diseases, including those due to Staphylococcus aureus and vancomycin-resistant Enterococcus [26-29]. Asymptomatic carriage of CD is common in hospitalized patients, and skin colonization with CD can be found in a great number of subjects up to 7 days after the resolution of CDI episodes. The risk of CDI and recurrence in hospitalized patients is extremely high [30]. Consequently, hand washing is one of the measures that are strongly recommended by clinical practice guidelines for the prevention of CDI and recurrence [14]. Unfortunately, CD is a pathogen with peculiar characteristics. It forms spores that are resistant to alcohol-based preparations [31], is poorly removed from contaminated hands by alcohol-based hand rubs [32] and can become the reason for CD transmission. This explains why the use of alcohol-based hand rubs has been debated. However, data collected in clinical trials specifically planned to evaluate the true efficacy of these products are reassuring, as an increase in CDI has never been reported [27,33-36]. The evidence that in patients with CDI, most of the CD that is recovered in the feces is in vegetative forms and only $10 \%$ as spores can explain this finding [36]. Vegetable forms of $\mathrm{CD}$ are highly sensitive to alcohol and can be eliminated when exposed to alcohol-containing preparations to effectively reduce the risk of transmission. According to the Australasian College of Infection Prevention and Control, it could be suggested that hands should be washed with soap and water or an antiseptic wash when they are visibly dirty/soiled, and hands should be disinfected with alcohol-based hand rub when they are visibly clean [37]. Moreover, healthcare workers must use gloves on entry to a room of a patient with CDI and while caring for patients with CDI. However, after removing gloves hand washing is mandatory [38].

Regardless of the limitations of each of the measures for infection control, the prevention of CDI can be strongly influenced by healthcare worker compliance with contact isolation precautions. Several studies have clearly shown that compliance is generally poor [39]. Adherence to all the recommended infection control measures is a complex, time-consuming process. Moreover, interventions are frequently not precisely defined, and recommendations are ambiguous [40]. In addition, a role in favoring poor adherence can be played by poor supply adequacy of personal protective equipment and hand-hygiene products. In a study in which compliance with all components of contact isolation precautions of health care workers of two hospitals was assessed, it was found that where compliance was poor, at least one supply item for contact isolation precautions was inadequate in most of the studied cases [41].

\section{Antibiotic Stewardship}

Antibiotic stewardship (AS), i.e., the implementation of programmes for the optimization of antibiotic use, is considered one of the most important measures to reduce the selection of host microbiota and the emergence of antimicrobial-resistant bacteria. Moreover, AS has been found to be associated with a significant reduction in antibiotic consumption, related adverse events, and costs for assistance in both hospital and community settings [42]. Use of almost all the antibiotics 
can increase risk of CDI development, although cephalosporins, fluoroquinolones, clindamycin, and some penicillins, such as co-amoxiclav, are those more frequently associated with these conditions [43]. Most of CDI cases, both in the hospital and in the community, have received antibiotics in the weeks before the diagnosis [42]. Starting from the evidence that antibiotic administration was the most important cause of CDI, it is not surprising that several attempts to rationalize antibiotic use through auditing, antibiotic restriction, antibiotic cycling or mixing, and the reduction of treatment duration to prevent CD colonization and infection have been carried out, mainly in the elderly population [43-65]. The results were generally very satisfactory, as most of these studies showed that the implementation of AS programmes was associated with a significant reduction in CDI incidence after antibiotic use. However, a number of studies, particularly quasi-experimental studies, had numerous potential biases [66], leading to debatable conclusions. In addition, in some cases, they were carried out during outbreaks [67], and the results do not represent what likely occurs in normal periods. Finally, studies were very heterogeneous [16]. Populations enrolled differed in demographic characteristics; underlying disease for which antibiotics were prescribed; the type, dosage, and schedule of drug administration; methods of CDI identification. AS interventions were frequently different and, in some cases, associated with one or more infection control measures. Consequently, although the use of AS interventions remains, together with infection control measures, the most effective available measure to prevent CDI infection after antibiotic therapy, which subjects have the greatest benefit from AS interventions is not precisely defined. Only a few studies included outpatients [16]; children were not considered; frequently, poor importance was ascribed to the underlying disease that justifies antibiotic prescription. It is not clarified which kind of AS interventions can be associated with the highest reduction of CDI risk; how long AS must be maintained; finally, which infection control measures can significantly contribute to limiting CDI development. Limitations of current knowledge on the role of AS in CDI prevention are clearly highlighted by the results of some systematic reviews and meta-analyses carried out using the most important studies in this regard. In a meta-analysis of 16 articles published before 2012 in which quasi-experimental or observational study designs were used and only hospitalized adults were included, AS was associated with a significant protective effect, as the risk of CDI development was reduced by more than $50 \%$ (relative risk (RR) 0.48 ; 95\% confidence interval (CI) 0.38-0.62). Complete removal of antibiotics or use allowed only after approval were the most effective types of interventions. However, only nine studies were considered of high quality, most of the data were collected in geriatric wards, the restriction of only fluoroquinolones and cephalosporins was analyzed, and AS duration varied from $\leq 9$ to $\geq 16$ months [68]. Slightly different results were evidenced by a more recent systematic review and meta-analysis [69] based on 11 studies performed up until 2016 that included only hospitalized patients. This study concluded a significant but lower benefit of AS than that found in the previous meta-analysis, as the reduction of CDI infection was only $32 \%$ (odds ratio (OR) OR 0.68; 95\% CI 0.53-0.88; $p=0.0029$ ). Different characteristics of the papers not included in the previous study and different methodologies used for analysis may explain this difference. The impact of the association of AS programmes with infection control measures was analyzed considering together the prevention of CD infection and the prevention of infection and colonization with antibiotic-resistant bacteria. This revealed that the association was more effective than AS alone (IR 0.69, 0.54-0.88; $p=0.0030$ ), especially when AS was associated with hand-hygiene interventions $(0.34,0.21-0.54 ; p<0.0001)$.

\section{Probiotics}

As antibiotic-related gut dysbiosis with the emergence of CD is the most important cause of CDI [13], it was supposed that the administration of probiotics, i.e., bacteria that confer a health benefit when ingested [70], could reconstitute normal gut microbiota composition and suppress CD colonization in patients given antimicrobial drugs [70]. The reliability of this supposition was measured by several studies. The effectiveness of probiotics was measured by comparing the incidence of CDI after antibiotic administration in patients given probiotics with that found in controls receiving 
placebo or no treatment. Unfortunately, most of the studies had several methodological limitations. Only in a few cases were randomized controlled trials (RCTs) performed. Moreover, studies were very heterogeneous. Patients with various antibiotic treatments given for different clinical conditions and with different risks of CDI development were enrolled. Inpatients and outpatients were simultaneously considered. Most of the studies were performed in older people. Various diarrhea definitions were used. Several probiotic preparations prescribed in different dosages for various periods of time were administered. Follow-up modalities and duration varied significantly. This explains why systematic reviews and meta-analyses of these studies have led to conflicting results or were unable to draw firm conclusions on the real efficacy of probiotics and how probiotic prophylaxis should be conducted. Only the safety of prophylaxis was clearly established [71-82]. Practically, regarding the prevention of CDI, whereas a positive effect was found in the reviews by Shen et al. [74] and Pattani et al. [80], no impact was reported in the meta-analysis by Goldenberg et al. [71] or in two RCTs [72,73]. For the prevention of CDI, probiotics were effective in two studies [71,77] but were not different from placebo or no treatment in three studies $[75,78,79]$.

A good example of the limited knowledge presently available regarding the prophylactic use of probiotics is given by some recent, well-conducted meta-analyses. The first of them is a Cochrane Review including 31 trials published up until March 2017 and 8672 individuals of different ages [71]. Only 10 studies were rated as having a low risk of bias, whereas 21 were considered to have a high or unclear risk of bias. Compared to controls, patients receiving probiotics were found to have a significantly lower risk of developing CDI both when all the studies were considered together and when only studies with a low risk of bias were analyzed. In both cases, CDI was reduced by $60 \%$. CDI occurred in approximately $1.5 \%$ of treated patients and in $4 \%$ of controls (RR $0.40,95 \%$ CI $0.30-0.52$ ). However, the clinical relevance of probiotics was relatively low, as it was calculated that to have an additional beneficial outcome, 42 patients had to be treated to prevent one case of CDI. A subgroup analysis revealed that no advantage from probiotics could be demonstrated in patients with a low risk of CDI development, whereas the benefit was increased to $70 \%$ in patients with a baseline risk $>5 \%$ (incidence of CDI $11.6 \%$ vs. $3.1 \%$, RR $0.30,95 \%$ CI $0.21-0.42$ ). However, contrary to what was evidenced for CDI prevention, probiotics did not influence CDI, i.e., the detection of CD in the stool. Pathogen detection was $15.5 \%$ in the probiotics group compared to $17.0 \%$ in the control group (RR $0.86,95 \%$ CI 0.67-1.10). Despite several thousand enrolled patients, the importance of probiotic dose and type in conditioning the development of CDAD could not be evaluated. The authors were unable to identify a credible dose-dependent or type-dependent effect, although in a study, it was found that the risk of CDIAD was lower with Lactobacillus acidophilus + Lactobacillus casei than with Lactobacillus rhamnosus (RR 0.21 vs. RR $0.63, p=0.03$ ). Finally, probiotics were safe, well tolerated, and capable of reducing the risk of adverse events associated with antibiotic administration by $17 \%$ (RR $0.83,95 \%$ CI $0.71-0.97$ ).

A more recent meta-analysis of randomized controlled trials published up until April 2016 including 6851 participants and most of the studies already considered in the previous meta-analysis was mainly directed to evaluate the impact of probiotics on the risk of CDI after antibiotic administration [83]. Most of the patients were adults, and in a non-marginal number of cases, risks of bias were evidenced. In this study, probiotic administration was associated with reduced CDI odds in both the unadjusted (OR $0.3795 \%$ CI 0.25-0.55) and the adjusted analysis (OR 0.35, 95\% CI, 0.23-0.55). Beneficial effects were more evident when two or more antibiotics were used (OR 2.20, 95\% CI 1.11-4.37). In contrast, no influence of age, sex, hospitalization, or the use of antibiotics at high risk of CDI was demonstrated. Prophylaxis with multispecies probiotics was more effective than no prophylaxis in reducing the risk of CDI (OR, $0.33 ; 95 \%$ CI, $0.20-0.56 ; p<0.0001)$. However, compared to single-species probiotics, prophylaxis with multispecies probiotics was only slightly more effective, with a difference that did not reach statistical significance (OR, $0.41,95 \% \mathrm{CI}, 0.17-1.00 ; p=0.051)$. Moreover, the effect was more evident when prophylaxis was prescribed in settings with a risk of $\mathrm{CDI} \geq 5 \%$. As several different preparations were used, differences in protection offered by the various probiotics could not be evaluated. However, comparison between Saccharomyces boulardii, the most frequently administered 
probiotic, and all the other bacteria did not show any difference (OR 0.86). Finally, serious adverse events were relatively uncommon and more frequent in subjects treated with high-risk antibiotics and in those receiving multiple antibiotic therapy. However, they were never considered attributable to probiotics and were equally distributed between subjects with and without probiotics in the unadjusted analyses (OR 1.06, 95\% CI, 0.89-1.26) and adjusted analyses (OR 1.06, 95\% CI, 0.89-1.28).

\section{Fecal Microbiota Transplantation}

As development of CDI, particularly recurrent cases, has been associated with significant variations of gut microbiota composition favoring $\mathrm{CD}$ colonization, restoring normal microbiota by fecal transplantations (FMT) from a healthy donor has been considered as a logical and practical solution to reduce the risk of new CDI episodes for many years [84]. However, although this measure has been endorsed by several organizations worldwide [85-87] and several reports seem to indicate that it can be effective in patients that were previously treated with standard therapeutic options with poor or no benefit [88-97], FMT remains debated [98]. Preferred method for administration, optimal donor selection, FMT preparation, route, timing, and number of administrations have not been defined and some of the randomized controlled trials that have studied its efficacy in clinical practice have significant limitations that make results debatable. In addition, it is not established whether FMT is per se effective or can be mainly considered an adjunctive treatment to antibiotics. Finally, safety can be debated as FMT has been associated with the development of severe infection. FDA has recently reported infections caused by enteropathogenic Escherichia coli and Shigatoxin-producing Escherichia coli that have occurred following use of FMT [99]. Starting from these premises, most of the experts consider FMT a viable treatment option for patients with multiple recurrences that have received without advantage appropriate antimicrobial therapy with metronidazole, vancomycin, or fidaxomicin. On the contrary, FMT cannot be considered a first choice prophylactic treatment to prevent CDI recurrences.

\section{Active and Passive Immunization}

Clinical manifestations of CDI are due to bacterial toxins. Most of CD strains produce two members of the large clostridial cytotoxin family, toxin A and toxin B, which are encoded by the genes $t c d A$ and $t c d B$, respectively, and are located within a five-gene locus known as the PaLoc. A restricted number of CD strains produce a third toxin named CD transferase [100]. As high levels of antibodies against $\mathrm{CD}$ toxins $\mathrm{A}$ and $\mathrm{B}$ correlate with the prevention of primary $\mathrm{CDI}$ and low rates of recurrences [101-104], and the administration of monoclonal antibodies against toxins is effective in reducing CDI recurrences [105], it was thought that active or passive immunization against toxins $\mathrm{A}$ and B could reduce the risk of CDI development. Consequently, vaccines and monoclonal antibodies against toxins have been studied. Moreover, the administration of hyperimmune colostrum-containing antibodies against CD was suggested [106]. However, as immunization against CD cannot reduce the risk of colonization, outgrowth, sporulation, and the release of the spores into the environment, favoring increased transmission of CDI, other preventive measures targeting CD surface cellular components or $\mathrm{CD}$ spores were developed.

\subsection{Vaccines}

Vaccines against $\mathrm{CD}$ are mainly intended for geriatric populations and adults at risk of CDI because of receiving frequent antibiotic treatment or with previous history of CDI. Among those based on $\mathrm{CD}$ toxins, a formalin-inactivated preparation of the toxins has been found safe and immunogenic in phase II clinical trials $[107,108]$. Despite these promising results, the vaccine was retired by the manufacturer after a phase III study showed that the probability of demonstrating that the vaccine could be effective and safe in the prevention of primary CDI was lower than expected [93].

The most advanced toxin-based $C D$ vaccine is a recombinant preparation that contains full-length genetically and chemically inactivated toxins A and B [109-111]. Phase I [110] and phase II studies [96] 
have shown that this vaccine was safe and immunogenic in adults aged 65-85 years [95]. This has supported the implementation of a phase III, placebo-controlled, randomized, observer-blinded study to evaluate the efficacy, safety, and tolerability of the vaccine in adults 50 years of age and older (NCT03090191). Enrolled patients had to receive three doses of the vaccine or placebo and had to be followed for up to 3 years after vaccination. The study is active but is no longer recruiting, with a completion date scheduled for September 2020. No results have been reported to date.

Additionally, worthy of interest is a vaccine based on a recombinant fusion protein comprising relevant epitopes of CD toxins. Even in this case, a phase I study has shown good safety and tolerability and excellent immunogenicity in healthy subjects aged $\geq 18$ years. Moreover, a phase II trial (NCT02316470) in which three doses of the vaccine were given to healthy subjects aged 50 to $>65$ showed that seroconversion was achieved in up to $83 \%$ of participants for antibodies against both toxins and up to $97 \%$ against toxin A alone. Unfortunately, as of now, no phase III trial has been planned, as the manufacturing company is seeking a partner to perform it.

Vaccines based on components of CD spores are in the very initial stage of development. Starting from the evidence that the inactivation of collagen-like exosporium protein BclA1 reduces the ability of $\mathrm{CD}$ to colonize mice [112], a vaccine containing BclA1 was prepared and tested in experimental animals [113]. The results were disappointing, as all the animals that had received the vaccine intraperitoneally died after challenge. However, it was suggested that these negative results did not exclude the possibility that a vaccine including collagen-like exosporium proteins may be effective. In the study by Ghose et al. [114], the vaccine was injected intraperitoneally, and this limited immune response as no mucosal immunity, of great importance for intestinal protection, could be evoked. Moreover, the CD strain used for the study encoded a truncated version of BclA1, and the immune response could be lower than desired. As most of the clinically relevant $C D$ strains express full-length BclA proteins, it was thought that a vaccine containing all these proteins, intramuscularly injected, could induce broader and protective immunity.

Another $\mathrm{CD}$ vaccine candidate based on structural components of the exosporium layer of pathogen spores is the CdeM vaccine. CdeM is a protein that controls the assembly of the exosporium layer [98], and a vaccine containing this protein was found to protect animals exposed to a virulent CD strain with a dose-dependent effect [113]. The protection of experimental animals from CDI was also reported when a vaccine based on $\mathrm{CdeC}$ protein, a second cysteine-rich protein that is supposed to form a protective structure around the spore coat [114], was used [115]. Finally, another vaccine target being considered is $\operatorname{Cot} \mathrm{A}$, another protein needed for the assembly of $\mathrm{CD}$ spores that is able to evoke a strong immune response [116-119]. The protection of $60 \%$ of mice immunized with a vaccine containing CotA was evidenced, suggesting potential possibilities for further development [117].

\subsection{Passive Immunization}

The administration of monoclonal antibodies against $\mathrm{CD}$ toxins $\mathrm{A}$ and $\mathrm{B}$ has been considered a potential measure to prevent CDI recurrences. Two different preparations, supposed to directly neutralize toxin A (actoxumab) and toxin B (bezlotoxumab), respectively, have been developed. Combined intravenous administration of these vaccines showed significant efficacy in an established hamster model of CDI [102]. Moreover, when passive immunization was added to metronidazole or vancomycin in patients with symptomatic CDI, recurrence rates were reduced, although the differences compared to controls were not statistically significant ( $8 \%$ vs. $32 \%, p=0.06)$. The difference in recurrence rate reached statistical significance when patients with more than one previous episode of CDI were separately considered ( $7 \%$ vs. 38\%, $p=0.006)$ [87]. However, when antibodies were given separately, it was found that only bezlotoxumab could protect experimental animals. Piglets receiving anti-toxin B antibodies were protected in 100\% of the cases from the development of systemic CDI with marginal gastrointestinal alterations. In contrast, animals receiving anti-toxin A antibodies suffered from severe systemic and gastrointestinal manifestations with death in the majority of cases [103]. As poor efficacy of actoxumab was confirmed in phase II and III clinical trials in humans $[88,104]$, further 
development was limited to bezlotoxumab. Data collected from two studies [105] enrolling patients with CDI treated with conventional antibiotic therapy showed that the addition of bezlotoxumab was significantly effective in reducing the risk of recurrence. In the first study, $17 \%$ of treated patients had a new episode of diarrhea in the 12 weeks after treatment compared with $28 \%$ of patients given placebo. In the second study, new diarrhea episodes occurred in $16 \%$ of treated patients and in $26 \%$ of placebo patients. In both cases, risk reduction was greater in patients at higher risk of recurrence. Unfortunately, no effect was found on the rate of initial cure. Both bezlotoxumab-treated patients and controls healed in $80 \%$ of the cases. This explains why, with the name Zinplava, bezlotoxumab has been approved in both the USA [120] and the European Union [121] only for prevention of recurrences in adults at high risk for recurrent CDI. The antibody was found to be generally safe and well tolerated, as the incidence rate of acute adverse events was similar in treated patients and controls. However, some concerns remain regarding potential health toxicity, as the incidence of heart failure in patients with a history of underlying congestive heart failure was significantly higher among those receiving bezlotoxumab than in controls ( $12.7 \%$ vs. $4.8 \%)$. Moreover, more deaths occurred among cases than among controls. Although heart failure and deaths were not infusion-related but were evidenced throughout the 3-month follow-up period and could not be directly linked to bezlotoxumab administration, this problem was considered when bezlotoxumab was licensed for clinical use in the USA. In the insert of the product marketed in the USA, the potential association with heart failure is mentioned, and it is highlighted that this antibody should be prescribed when the supposed benefit outweighs risk [122]. However, this is not reported in the insert of the product marketed in the EU [123].

A particular aspect of passive immunization is oral administration of hyperimmune whey derived from colostrum or mature milk of cows immunized to obtain secretory immunoglobulin A against the two toxins, TcdA and TcdB, as well as CD. Studies carried out in experimental animals are promising as whey protected animals from death, in contrast to standard antibiotic therapy [124]. However, data collected in humans are very few, although in one of these studies, hyperimmune whey was found to be as effective as metronidazole in the prevention of CDI recurrences [125-128]. Moreover, better characterization of this kind of immunotherapy and more knowledge on its mechanism of action are needed before this prophylactic measure can be considered for clinical use.

\section{Conclusions}

CDI is a significant clinical, social, and economic problem. Table 1 summarizes preventive strategies against CDI. The prevention of primary infection, the diffusion of pathogens, and the development of recurrences seems essential to reduce the total burden due to this pathogen. Unfortunately, despite several studies, the prevention of CD-related problems remains difficult. This seems particularly true for cases that develop in the community and in older children and young adults, as almost all the data presently available have been collected in the hospital and in the elderly population. Practically, only interventions usually recommended for infection control and prevention can reduce CDI, although their use to reduce CD-related problems is not precisely defined, and some aspects remain debated. Moreover, compliance with recommendations is generally poor. Novel strategies for prevention, such as those based on the use of probiotics and active and passive immunization, have not yet been fully developed. Studies specifically devoted to establishing whether probiotics can be effective and defining which type of bacteria, dosage, and duration of administration can reduce the risk of CDI are urgently needed before probiotics can be included among measures for prevention. Totally imaginative and hardly applicative in clinical practice is the use of whey proteins derived from colostrum or breast milk from immunized cows. Several vaccines have been developed. The most advanced methods have significant limitations as they cannot prevent colonization and development of primary CDI. Only vaccines able to face these problems can allow a resolutive approach to the total burden due to this pathogen. 
Table 1. Strategies for prevention against Clostridium difficile infection (CDI).

\begin{tabular}{|c|c|}
\hline Strategy & Action \\
\hline Infection control measures & $\begin{array}{l}\text { Prompt identification of patients with suspected CDI } \\
\text { Isolation of suspected and documented cases } \\
\text { Disinfection of the patient's room and objects } \\
\text { Use of contact isolation measures such as gloves and gowns }\end{array}$ \\
\hline Antibiotic stewardship & $\begin{array}{l}\text { Implementation of programmes for the optimization of antibiotic use, is } \\
\text { considered one of the most important measures to reduce the selection of host } \\
\text { microbiota and the emergence of antimicrobial-resistant bacteria. }\end{array}$ \\
\hline Probiotics & $\begin{array}{l}\text { Administration of bacteria that confer a health benefit when ingested could } \\
\text { reconstitute normal gut microbiota composition and suppress CD colonization } \\
\text { in patients given antimicrobial drugs }\end{array}$ \\
\hline Active immunization & $\begin{array}{l}\text { Toxin-based CD vaccine } \\
\text { Vaccine based on a recombinant fusion protein comprising relevant epitopes of } \\
\mathrm{CD} \text { toxins } \\
\text { Vaccine based on components of } \mathrm{CD} \text { spores } \\
\text { Vaccine based on the structural components of the exosporium layer of } \\
\text { pathogen spores }\end{array}$ \\
\hline Passive immunization & $\begin{array}{l}\text { Monoclonal antibodies against } C D \text { toxins } A \text { (actoxumab) and B (bezlotoxumab) } \\
\text { Oral administration of hyperimmune whey derived from colostrum or mature } \\
\text { milk of cows immunized to obtain secretory immunoglobulin A against the two } \\
\text { toxins, } A \text { and } B \text {, as well as CD }\end{array}$ \\
\hline
\end{tabular}

Author Contributions: N.P. wrote the first draft of the manuscript. M.G. (Margherita Gnocchi), M.G. (Martina Gagliardi), A.A. and C.N. performed the literature analysis. S.E. cowrote the manuscript, critically revised the text, and made substantial scientific contributions. All authors have read and agreed to the published version of the manuscript.

Funding: This research received no external funding.

Conflicts of Interest: The authors declare no conflict of interest.

\section{References}

1. Bartlett, J.G. Clostridium difficile Infection. Infect. Dis. Clin. N. Am. 2017, 31, 489-495. [CrossRef]

2. Leffler, D.A.; Lamont, J.T. Clostridium difficile infection. N. Engl. J. Med. 2015, 372, 1539-1548. [CrossRef] [PubMed]

3. European Center for Disease Prevention and Control. European Surveillance of Clostridioides (Clostridium) Difficile Infections. Surveillance Protocol Version 2.4. 2019. Available online: https://www.ecdc.europa.eu/ sites/default/files/documents/clostridium-difficile-infections-EU-surveillance-protocol-vers2.4.pdf (accessed on 28 September 2020).

4. Leffler, D.A.; Lamont, J.T. Editorial: Not so nosocomial anymore: The growing threat of community-acquired Clostridium difficile. Am. J. Gastroenterol. 2012, 107, 96-98. [CrossRef] [PubMed]

5. Lessa, F.C.; Mu, Y.; Bamberg, W.M.; Beldavs, Z.G.; Dumyati, G.K.; Dunn, J.R.; Farley, M.M.; Holzbauer, S.M.; Meek, J.I.; Phipps, E.C.; et al. Burden of Clostridium difficile infection in the United States. N. Engl. J. Med. 2015, 372, 825-834. [CrossRef]

6. Sholeh, M.; Krutova, M.; Forouzesh, M.; Mironov, S.; Sadeghifard, N.; Molaeipour, L.; Maleki, A.; Kouhsari, E. Antimicrobial resistance in Clostridioides (Clostridium) difficile derived from humans: A systematic review and meta-analysis. Antimicrob. Resist. Infect. Control. 2020, 9, 158. [CrossRef]

7. European Center for Diseease Prevention and Control. Surveillance Report. Point Prevalence Survey of Healthcare-Associated Infections and Antimicrobial Use in European Acute Care Hospitals 2011-2012. Available online: https:/www.ecdc.europa.eu/sites/portal/files/media/en/publications/Publications/healthcare-associatedinfections-antimicrobial-use-PPS.pdf (accessed on 28 September 2020).

8. Bouwknegt, M.; van Dorp, S.; Kuijper, E. Burden of Clostridium difficile infection in the United States. N. Engl. J. Med. 2015, 372, 2368. [CrossRef] 
9. Desai, K.; Gupta, S.B.; Dubberke, E.R.; Prabhu, V.S.; Browne, C.; Mast, T.C. Epidemiological and economic burden of Clostridium difficile in the United States: Estimates from a modeling approach. BMC Infect. Dis. 2016, 16, 303. [CrossRef]

10. Miller, M.; Gravel, D.; Mulvey, M.; Taylor, G.; Boyd, D.; Simor, A.; Gardam, M.; McGeer, A.; Hutchinson, J.; Moore, D.; et al. Health care-associated Clostridium difficile infection in Canada: Patient age and infecting strain type are highly predictive of severe outcome and mortality. Clin. Infect Dis. 2010, 50, 194-201. [CrossRef]

11. Lucado, J.; Gould, C.; Elixhauser, A. Clostridium Difficile Infections (CDI) in Hospital Stays, 2009: Statistical Brief \#124. In Healthcare Cost and Utilization Project (HCUP) Statistical Briefs; Agency for Healthcare Research and Quality (US): Rockville, MD, USA, 2006.

12. Ricciardi, R.; Rothenberger, D.A.; Madoff, R.D.; Baxter, N.N. Increasing prevalence and severity of Clostridium difficile colitis in hospitalized patients in the United States. Arch. Surg. 2007, 142, 624-631; discussion 631. [CrossRef]

13. Kola, A.; Wiuff, C.; Akerlund, T.; van Benthem, B.H.; Coignard, B.; Lyytikäinen, O.; Weitzel-Kage, D.; Suetens, C.; Wilcox, M.H.; Kuijper, E.J.; et al. Survey of Clostridium difficile infection surveillance systems in Europe, 2011. Eurosurveillance 2016, 21. [CrossRef]

14. Badger, V.O.; Ledeboer, N.A.; Graham, M.B.; Edmiston, C.E., Jr. Clostridium difficile: Epidemiology, pathogenesis, management, and prevention of a recalcitrant healthcare-associated pathogen. JPEN J. Parenter Enteral Nutr. 2012, 36, 645-662. [CrossRef] [PubMed]

15. Johnson, S. Recurrent Clostridium difficile infection: A review of risk factors, treatments, and outcomes. J. Infect. 2009, 58, 403-410. [CrossRef]

16. Zhang, D.; Prabhu, V.S.; Marcella, S.W. Attributable Healthcare Resource Utilization and Costs for Patients With Primary and Recurrent Clostridium difficile Infection in the United States. Clin. Infect. Dis. 2018, 66, 1326-1332. [CrossRef] [PubMed]

17. Lytvyn, L.; Mertz, D.; Sadeghirad, B.; Alaklobi, F.; Selva, A.; Alonso-Coello, P.; Johnston, B.C. Prevention of Clostridium difficile Infection: A Systematic Survey of Clinical Practice Guidelines. Infect. Control Hosp. Epidemiol. 2016, 37, 901-908. [CrossRef]

18. Dubberke, E.R.; Carling, P.; Carrico, R.; Donskey, C.J.; Loo, V.G.; McDonald, L.C.; Maragakis, L.L.; Sandora, T.J.; Weber, D.J.; Yokoe, D.S.; et al. Strategies to prevent Clostridium difficile infections in acute care hospitals: 2014 update. Infect. Control Hosp. Epidemiol. 2014, 35 (Suppl. 2), S48-S65. [CrossRef] [PubMed]

19. Tschudin-Sutter, S.; Kuijper, E.J.; Durovic, A.; Vehreschild, M.J.G.T.; Barbut, F.; Eckert, C.; Fitzpatrick, F.; Hell, M.; Norèn, T.; O'Driscoll, J.; et al. Guidance document for prevention of Clostridium difficile infection in acute healthcare settings. Clin. Microbiol. Infect. 2018, 24, 1051-1054. [CrossRef]

20. Williams, D.; Adcock, L. CADTH Rapid Response Reports. In Probiotics for Antibiotic-Associated Diarrhea and Clostridium difficile Infection: A Review of Clinical Effectiveness; Canadian Agency for Drugs and Technologies in Health 2018: Ottawa, ON, USA, 2018.

21. Haber, S.L.; Raney, C.R.K.; Larson, T.L.; Lau, J.P. Fecal microbiota transplantation for recurrent Clostridioides difficile infection. Am. J. Health Syst. Pharm. 2019, 76, 935-942. [CrossRef]

22. Carroll, K.C.; Mizusawa, M. Laboratory Tests for the Diagnosis of Clostridium difficile. Clin. Colon. Rectal Surg. 2020, 33, 73-81. [CrossRef]

23. Shaughnessy, M.K.; Micielli, R.L.; DePestel, D.D.; Arndt, J.; Strachan, C.L.; Welch, K.B.; Chenoweth, C.E. Evaluation of hospital room assignment and acquisition of Clostridium difficile infection. Infect. Control Hosp. Epidemiol. 2011, 32, 201-206. [CrossRef]

24. Chang, V.T.; Nelson, K. The role of physical proximity in nosocomial diarrhea. Clin. Infect Dis. 2000, 31, 717-722. [CrossRef]

25. Clabots, C.R.; Johnson, S.; Olson, M.M.; Peterson, L.R.; Gerding, D.N. Acquisition of Clostridium difficile by hospitalized patients: Evidence for colonized new admissions as a source of infection. J. Infect Dis. 1992, 166, 561-567. [CrossRef] [PubMed]

26. Mayfield, J.L.; Leet, T.; Miller, J.; Mundy, L.M. Environmental control to reduce transmission of Clostridium difficile. Clin. Infect Dis. 2000, 31, 995-1000. [CrossRef] [PubMed] 
27. Kaier, K.; Hagist, C.; Frank, U.; Conrad, A.; Meyer, E. Two time-series analyses of the impact of antibiotic consumption and alcohol-based hand disinfection on the incidences of nosocomial methicillin-resistant Staphylococcus aureus infection and Clostridium difficile infection. Infect. Control Hosp. Epidemiol. 2009, 30, 346-353. [CrossRef] [PubMed]

28. Gordin, F.M.; Schultz, M.E.; Huber, R.A.; Gill, J.A. Reduction in nosocomial transmission of drug-resistant bacteria after introduction of an alcohol-based handrub. Infect. Control Hosp. Epidemiol. 2005, 26, 650-653. [CrossRef] [PubMed]

29. Vernaz, N.; Sax, H.; Pittet, D.; Bonnabry, P.; Schrenzel, J.; Harbarth, S. Temporal effects of antibiotic use and hand rub consumption on the incidence of MRSA and Clostridium difficile. J. Antimicrob. Chemother. 2008, 62, 601-607. [CrossRef] [PubMed]

30. Bobulsky, G.S.; Al-Nassir, W.N.; Riggs, M.M.; Sethi, A.K.; Donskey, C.J. Clostridium difficile skin contamination in patients with C. difficile-associated disease. Clin. Infect. Dis. 2008, 46, 447-450. [CrossRef]

31. Wullt, M.; Odenholt, I.; Walder, M. Activity of three disinfectants and acidified nitrite against Clostridium difficile spores. Infect. Control Hosp. Epidemiol. 2003, 24, 765-768. [CrossRef]

32. Boyce, J.M.; Ligi, C.; Kohan, C.; Dumigan, D.; Havill, N.L. Lack of association between the increased incidence of Clostridium difficile-associated disease and the increasing use of alcohol-based hand rubs. Infect. Control Hosp. Epidemiol. 2006, 27, 479-483. [CrossRef]

33. Jabbar, U.; Leischner, J.; Kasper, D.; Gerber, R.; Sambol, S.P.; Parada, J.P.; Johnson, S.; Gerding, D.N. Effectiveness of alcohol-based hand rubs for removal of Clostridium difficile spores from hands. Infect. Control Hosp. Epidemiol. 2010, 31, 565-570. [CrossRef]

34. Gopal Rao, G.; Jeanes, A.; Osman, M.; Aylott, C.; Green, J. Marketing hand hygiene in hospitals-a case study. J. Hosp. Infect. 2002, 50, 42-47. [CrossRef]

35. Knight, N.; Strait, T.; Anthony, N.; Lovell, R.; Norton, H.J.; Sautter, R.; Scobey, M. Clostridium difficile colitis: A retrospective study of incidence and severity before and after institution of an alcohol-based hand rub policy. Am. J. Infect. Control 2010, 38, 523-528. [CrossRef] [PubMed]

36. Rupp, M.E.; Fitzgerald, T.; Puumala, S.; Anderson, J.R.; Craig, R.; Iwen, P.C.; Jourdan, D.; Keuchel, J.; Marion, N.; Peterson, D.; et al. Prospective, controlled, cross-over trial of alcohol-based hand gel in critical care units. Infect. Control Hosp. Epidemiol. 2008, 29, 8-15. [CrossRef] [PubMed]

37. Jump, R.L.; Pultz, M.J.; Donskey, C.J. Vegetative Clostridium difficile survives in room air on moist surfaces and in gastric contents with reduced acidity: A potential mechanism to explain the association between proton pump inhibitors and C. difficile-associated diarrhea? Antimicrob. Agents Chemother. 2007, 51, 2883-2887. [CrossRef]

38. Stuart, R.L.; Marshall, C.; Harrington, G.; Sasko, L.; McLaws, M.L.; Ferguson, J. ASID/ACIPC position statement-Infection control for patients with Clostridium difficile infection in healthcare facilities. Infect. Dis. Health 2019, 24, 32-43. [CrossRef]

39. Dhar, S.; Marchaim, D.; Tansek, R.; Chopra, T.; Yousuf, A.; Bhargava, A.; Martin, E.T.; Talbot, T.R.; Johnson, L.E.; Hingwe, A.; et al. Contact precautions: More is not necessarily better. Infect. Control Hosp. Epidemiol. 2014, 35, 213-221. [CrossRef] [PubMed]

40. Gurses, A.P.; Seidl, K.L.; Vaidya, V.; Bochicchio, G.; Harris, A.D.; Hebden, J.; Xiao, Y. Systems ambiguity and guideline compliance: A qualitative study of how intensive care units follow evidence-based guidelines to reduce healthcare-associated infections. Qual. Saf. Health Care 2008, 17, 351-359. [CrossRef]

41. Yanke, E.; Zellmer, C.; Van Hoof, S.; Moriarty, H.; Carayon, P.; Safdar, N. Understanding the current state of infection prevention to prevent Clostridium difficile infection: A human factors and systems engineering approach. Am. J. Infect. Control 2015, 43, 241-247. [CrossRef]

42. Tacconelli, E.; Cataldo, M.A.; Dancer, S.J.; De Angelis, G.; Falcone, M.; Frank, U.; Kahlmeter, G.; Pan, A.; Petrosillo, N.; Rodríguez-Baño, J.; et al. ESCMID guidelines for the management of the infection control measures to reduce transmission of multidrug-resistant Gram-negative bacteria in hospitalized patients. Clin. Microbiol. Infect. 2014, 20 (Suppl. 1), 1-55. [CrossRef]

43. Principi, N.; Esposito, S. Antimicrobial stewardship in paediatrics. BMC Infect. Dis. 2016, 16, 424. [CrossRef]

44. Deshpande, A.; Pasupuleti, V.; Thota, P.; Pant, C.; Rolston, D.D.; Sferra, T.J.; Hernandez, A.V.; Donskey, C.J. Community-associated Clostridium difficile infection and antibiotics: A meta-analysis. J. Antimicrob. Chemother. 2013, 68, 1951-1961. [CrossRef] 
45. Mullish, B.H.; Williams, H.R. Clostridium difficile infection and antibiotic-associated diarrhoea. Clin. Med. 2018, 18, 237-241. [CrossRef]

46. Elligsen, M.; Walker, S.A.; Pinto, R.; Simor, A.; Mubareka, S.; Rachlis, A.; Allen, V.; Daneman, N. Audit and feedback to reduce broad-spectrum antibiotic use among intensive care unit patients: A controlled interrupted time series analysis. Infect. Control Hosp. Epidemiol. 2012, 33, 354-361. [CrossRef]

47. Fowler, S.; Webber, A.; Cooper, B.S.; Phimister, A.; Price, K.; Carter, Y.; Kibbler, C.C.; Simpson, A.J.; Stone, S.P. Successful use of feedback to improve antibiotic prescribing and reduce Clostridium difficile infection: A controlled interrupted time series. J. Antimicrob. Chemother. 2007, 59, 990-995. [CrossRef] [PubMed]

48. Frank, M.O.; Batteiger, B.E.; Sorensen, S.J.; Hartstein, A.I.; Carr, J.A.; McComb, J.S.; Clark, C.D.; Abel, S.R.; Mikuta, J.M.; Jones, R.B. Decrease in expenditures and selected nosocomial infections following implementation of an antimicrobial-prescribing improvement program. Clin. Perform. Qual. Health Care 1997, 5, 180-188.

49. Gulihar, A.; Nixon, M.; Jenkins, D.; Taylor, G.J. Clostridium difficile in hip fracture patients: Prevention, treatment and associated mortality. Injury 2009, 40, 746-751. [CrossRef] [PubMed]

50. Jones, E.M.; Kirkpatrick, B.L.; Feeney, R.; Reeves, D.S.; MacGowan, A.P. Hospital-acquired Clostridium difficile diarrhoea. Lancet 1997, 349, 1176-1177. [CrossRef]

51. Ludlam, H.; Brown, N.; Sule, O.; Redpath, C.; Coni, N.; Owen, G. An antibiotic policy associated with reduced risk of Clostridium difficile-associated diarrhoea. Age Ageing 1999, 28, 578-580. [CrossRef]

52. Malani, A.N.; Richards, P.G.; Kapila, S.; Otto, M.H.; Czerwinski, J.; Singal, B. Clinical and economic outcomes from a community hospital's antimicrobial stewardship program. Am. J. Infect. Control 2013, 41, 145-148. [CrossRef] [PubMed]

53. Miller, A.; Carr, B. The impact of an antibiotic policy change on Clostridium difficile infection in a UK teaching hospital intensive care unit Abstracts of the Twenty-second ESICM Annual Congress. Intensive Care Med. 2009, 35, S207.

54. O'Connor, K.A.; Kingston, M.; O’Donovan, M.; Cryan, B.; Twomey, C.; O’Mahony, D. Antibiotic prescribing policy and Clostridium difficile diarrhoea. QJM 2004, 97, 423-429. [CrossRef]

55. Price, J.; Cheek, E.; Lippett, S.; Cubbon, M.; Gerding, D.N.; Sambol, S.P.; Citron, D.M.; Llewelyn, M. Impact of an intervention to control Clostridium difficile infection on hospital- and community-onset disease; an interrupted time series analysis. Clin. Microbiol. Infect. 2010, 16, 1297-1302. [CrossRef]

56. Cobo Reinoso, J.; Oliva Domínguez, J.; Soler Vigil, M.; Martínez-Beltrán, J.; Pedraza Cezón, L.; Moreno Guillén, S. Evaluation of an advisory program in antibiotic therapy. Rev. Clin. Esp. 2002, 202, 78-83. [CrossRef]

57. Schön, T.; Sandelin, L.L.; Bonnedahl, J.; Hedebäck, F.; Wistedt, A.; Brudin, L.; Jarnheimer, P. A comparative study of three methods to evaluate an intervention to improve empirical antibiotic therapy for acute bacterial infections in hospitalized patients. Scand J. Infect. Dis. 2011, 43, 251-257. [CrossRef] [PubMed]

58. Starks, I.; Ayub, G.; Walley, G.; Orendi, J.; Roberts, P.; Maffulli, N. Single-dose cefuroxime with gentamicin reduces Clostridium difficile-associated disease in hip-fracture patients. J. Hosp. Infect. 2008, 70, 21-26. [CrossRef] [PubMed]

59. Stone, S.P.; Beric, V.; Quick, A.; Balestrini, A.A.; Kibbler, C.C. The effect of an enhanced infection-control policy on the incidence of Clostridium difficile infection and methicillin-resistant Staphyloccocus aureus colonization in acute elderly medical patients. Age Ageing 1998, 27, 561-568. [CrossRef]

60. Talpaert, M.J.; Gopal Rao, G.; Cooper, B.S.; Wade, P. Impact of guidelines and enhanced antibiotic stewardship on reducing broad-spectrum antibiotic usage and its effect on incidence of Clostridium difficile infection. J. Antimicrob. Chemother. 2011, 66, 2168-2174. [CrossRef]

61. Thomas, C.; Stevenson, M.; Williamson, D.J.; Riley, T.V. Clostridium difficile-associated diarrhea: Epidemiological data from Western Australia associated with a modified antibiotic policy. Clin. Infect. Dis. 2002, 35, 1457-1462. [CrossRef]

62. Borde, J.P.; Litterst, S.; Ruhnke, M.; Feik, R.; Hübner, J.; deWith, K.; Kaier, K.; Kern, W.V. Implementing an intensified antibiotic stewardship programme targeting cephalosporin and fluoroquinolone use in a 200-bed community hospital in Germany. Infection 2015, 43, 45-50. [CrossRef]

63. Cruz-Rodríguez, N.C.; Hernández-García, R.; Salinas-Caballero, A.G.; Pérez-Rodríguez, E.; Garza-González, E.; Camacho-Ortiz, A. The effect of pharmacy restriction of clindamycin on Clostridium difficile infection rates in an orthopedics ward. Am. J. Infect. Control 2014, 42, e71-e73. [CrossRef] 
64. Lübbert, C.; Schumacher, U.; Stareprawo, S.; Claus, J.; Heeß-Erler, G.; Fiebig, C.; de With, K.; Wilhelms, D.; Kekulé, A.S.; Klöss, T.; et al. Can the antibiotic prescription practice in a hospital be influenced by in-house guidelines? An interventional study at the University Hospital Halle (Saale), Germany. Dtsch. Med. Wochenschr. 2014, 139, 2578-2584. [CrossRef]

65. Dubrovskaya, Y.; Papadopoulos, J.; Scipione, M.R.; Altshuler, J.; Phillips, M.; Mehta, S.A. Antibiotic stewardship for intra-abdominal infections: Early impact on antimicrobial use and patient outcomes. Infect. Control Hosp. Epidemiol. 2012, 33, 427-429. [CrossRef] [PubMed]

66. Leung, V.; Gill, S.; Sauve, J.; Walker, K.; Stumpo, C.; Powis, J. Growing a "positive culture" of antimicrobial stewardship in a community hospital. Can J. Hosp. Pharm. 2011, 64, 314-320. [CrossRef] [PubMed]

67. Cook, P.P.; Gooch, M. Long-term effects of an antimicrobial stewardship programme at a tertiary-care teaching hospital. Int. J. Antimicrob. Agents 2015, 45, 262-267. [CrossRef] [PubMed]

68. McNulty, C.; Logan, M.; Donald, I.P.; Ennis, D.; Taylor, D.; Baldwin, R.N.; Bannerjee, M.; Cartwright, K.A. Successful control of Clostridium difficile infection in an elderly care unit through use of a restrictive antibiotic policy. J. Antimicrob. Chemother. 1997, 40, 707-711. [CrossRef] [PubMed]

69. Harris, A.D.; Bradham, D.D.; Baumgarten, M.; Zuckerman, I.H.; Fink, J.C.; Perencevich, E.N. The use and interpretation of quasi-experimental studies in infectious diseases. Clin. Infect. Dis. 2004, 38, 1586-1591. [CrossRef]

70. Stone, S.P.; Cooper, B.S.; Kibbler, C.C.; Cookson, B.D.; Roberts, J.A.; Medley, G.F.; Duckworth, G.; Lai, R.; Ebrahim, S.; Brown, E.M.; et al. The ORION statement: Guidelines for transparent reporting of outbreak reports and intervention studies of nosocomial infection. Lancet Infect. Dis. 2007, 7, 282-288. [CrossRef]

71. Feazel, L.M.; Malhotra, A.; Perencevich, E.N.; Kaboli, P.; Diekema, D.J.; Schweizer, M.L. Effect of antibiotic stewardship programmes on Clostridium difficile incidence: A systematic review and meta-analysis. J. Antimicrob. Chemother. 2014, 69, 1748-1754. [CrossRef]

72. Baur, D.; Gladstone, B.P.; Burkert, F.; Carrara, E.; Foschi, F.; Döbele, S.; Tacconelli, E. Effect of antibiotic stewardship on the incidence of infection and colonisation with antibiotic-resistant bacteria and Clostridium difficile infection: A systematic review and meta-analysis. Lancet Infect. Dis. 2017, 17, 990-1001. [CrossRef]

73. Taibi, A.; Comelli, E.M. Practical approaches to probiotics use. Appl. Physiol. Nutr. Metab. 2014, 39, 980-986. [CrossRef]

74. Goldenberg, J.Z.; Yap, C.; Lytvyn, L.; Lo, C.K.; Beardsley, J.; Mertz, D.; Johnston, B.C. Probiotics for the prevention of Clostridium difficile-associated diarrhea in adults and children. Cochrane Database Syst. Rev. 2017, 12, Cd006095. [CrossRef]

75. McFarland, L.V.; Evans, C.T.; Goldstein, E.J.C. Strain-Specificity and Disease-Specificity of Probiotic Efficacy: A Systematic Review and Meta-Analysis. Front. Med. 2018, 5, 124. [CrossRef] [PubMed]

76. Blaabjerg, S.; Artzi, D.M.; Aabenhus, R. Probiotics for the Prevention of Antibiotic-Associated Diarrhea in Outpatients-A Systematic Review and Meta-Analysis. Antibiotics 2017, 6, 21. [CrossRef] [PubMed]

77. Shen, N.T.; Maw, A.; Tmanova, L.L.; Pino, A.; Ancy, K.; Crawford, C.V.; Simon, M.S.; Evans, A.T. Timely Use of Probiotics in Hospitalized Adults Prevents Clostridium difficile Infection: A Systematic Review With Meta-Regression Analysis. Gastroenterology 2017, 152, 1889-1900. [CrossRef] [PubMed]

78. Vernaya, M.; McAdam, J.; Hampton, M.D. Effectiveness of probiotics in reducing the incidence of Clostridium difficile-associated diarrhea in elderly patients: A systematic review. JBI Database Syst. Rev. Implement Rep. 2017, 15, 140-164. [CrossRef]

79. Jafarnejad, S.; Shab-Bidar, S.; Speakman, J.R.; Parastui, K.; Daneshi-Maskooni, M.; Djafarian, K. Probiotics Reduce the Risk of Antibiotic-Associated Diarrhea in Adults (18-64 Years) but Not the Elderly (>65 Years): A Meta-Analysis. Nutr. Clin. Pract. 2016, 31, 502-513. [CrossRef]

80. Sinclair, A.; Xie, X.; Saab, L.; Dendukuri, N. Lactobacillus probiotics in the prevention of diarrhea associated with Clostridium difficile: A systematic review and Bayesian hierarchical meta-analysis. CMAJ Open 2016, 4, E706-E718. [CrossRef]

81. Szajewska, H.; Kołodziej, M. Systematic review with meta-analysis: Saccharomyces boulardii in the prevention of antibiotic-associated diarrhoea. Aliment. Pharmacol. Ther. 2015, 42, 793-801. [CrossRef]

82. Xie, C.; Li, J.; Wang, K.; Li, Q.; Chen, D. Probiotics for the prevention of antibiotic-associated diarrhoea in older patients: A systematic review. Travel. Med. Infect. Dis. 2015, 13, 128-134. [CrossRef] [PubMed] 
83. Pattani, R.; Palda, V.A.; Hwang, S.W.; Shah, P.S. Probiotics for the prevention of antibiotic-associated diarrhea and Clostridium difficile infection among hospitalized patients: Systematic review and meta-analysis. Open Med. 2013, 7, e56-e67.

84. Barker, A.K.; Duster, M.; Valentine, S.; Hess, T.; Archbald-Pannone, L.; Guerrant, R.; Safdar, N. A randomized controlled trial of probiotics for Clostridium difficile infection in adults (PICO). J. Antimicrob. Chemother. 2017, 72, 3177-3180. [CrossRef]

85. Barone, A.; Marchionni, F.S.; Cinquini, C.; Cipolli Panattoni, A.; Toti, P.; Marconcini, S.; Covani, U.; Gabriele, M. Antibiotic treatment to prevent postextraction complications: A monocentric, randomized clinical trial. Preliminary outcomes. Minerva Stomatol. 2017, 66, 148-156. [CrossRef] [PubMed]

86. Johnston, B.C.; Lytvyn, L.; Lo, C.K.; Allen, S.J.; Wang, D.; Szajewska, H.; Miller, M.; Ehrhardt, S.; Sampalis, J.; Duman, D.G.; et al. Microbial Preparations (Probiotics) for the Prevention of Clostridium difficile Infection in Adults and Children: An Individual Patient Data Meta-analysis of 6,851 Participants. Infect. Control Hosp. Epidemiol. 2018, 39, 771-781. [CrossRef] [PubMed]

87. Eiseman, B.; Silen, W.; Bascom, G.S.; Kauvar, A.J. Fecal enema as an adjunct in the treatment of pseudomembranous enterocolitis. Surgery 1958, 44, 854-859. [PubMed]

88. McDonald, L.C.; Gerding, D.N.; Johnson, S. Clinical practice guidelines for Clostridium difficile infection in adults and children: 2017 update by the Infectious Diseases Society of America (IDSA) and Society for Healthcare Epidemiology of America (SHEA). Clin. Infect. Dis. 2018, 66, e1-e48. [CrossRef] [PubMed]

89. Debast, S.B.; Bauer, M.P.; Kuijper, E.J. European society of clinical microbiology and infectious diseases: Update of the treatment guidance document for Clostridium difficile infection. Clin. Microbiol. Infect. 2004, 20 (Suppl. 2), 1-26. [CrossRef]

90. Trubiano, J.A.; Cheng, A.C.; Korman, T.M.; Roder, C.; Campbell, A.; May, M.L.A.; Blyth, C.C.; Ferguson, J.K.; Blackmore, T.K.; Riley, T.V.; et al. Australasian Society of Infectious Diseases updated guidelines for the management of Clostridium difficile infection in adults and children in Australia and New Zealand. Int. Med. J. 2016, 46, 479-493. [CrossRef]

91. Van Nood, E.; Dijkgraaf, M.G.; Keller, J.J. Duodenal infusion of feces for recurrent Clostridium difficile. N. Engl. J. Med. 2013, 368, 2145. [CrossRef]

92. Cammarota, G.; Masucci, L.; Ianiro, G.; Bibbò, S.; Dinoi, G.; Costamagna, G.; Sanguinetti, M.; Gasbarrini, A. Randomised clinical trial: Faecal microbiota transplantation by colonoscopy vs. vancomycin for the treatment of recurrent Clostridium difficile infection. Aliment. Pharmacol. Ther. 2015, 41, 835-843. [CrossRef]

93. Hota, S.S.; Sales, V.; Tomlinson, G.; Salpeter, M.J.; McGeer, A.; Coburn, B.; Guttman, D.S.; Low, D.E.; Poutanen, S.M. Oral vancomycin followed by fecal transplantation versus tapering oral vancomycin treatment for recurrent Clostridium difficile infection: An open-label, randomized controlled trial. Clin. Infect. Dis. 2017, 64, 265-271. [CrossRef]

94. Hvas, C.L.; Jørgensen, S.M.D.; Jørgensen, S.P.; Storgaard, M.; Lemming, L.; Hansen, M.M.; Erikstrup, C.; Dahlerup, J.F. Fecal microbiota transplantation is superior to fidaxomicin for treatment of recurrent Clostridium difficile infection. Gastroenterology 2019, 156, 1324-1332. [CrossRef]

95. Youngster, I.; Sauk, J.; Pindar, C.; Wilson, R.G.; Kaplan, J.L.; Smith, M.B.; Alm, E.J.; Gevers, D.; Russell, G.H.; Hohmann, E.L. Fecal microbiota transplant for relapsing Clostridium difficile infection using a frozen inoculum from unrelated donors: A randomized, open-label, controlled pilot study. Clin. Infect. Dis. 2014, 58, 1515-1522. [CrossRef]

96. Youngster, I.; Sauk, J.; Pindar, C.; Wilson, R.G.; Kaplan, J.L.; Smith, M.B.; Alm, E.J.; Gevers, D.; Russell, G.H.; Hohmann, E.L. Frozen vs fresh fecal microbiota transplantation and clinical resolution of diarrhea in patients with recurrent Clostridium difficile infection: A randomized clinical trial. JAMA 2016, 315, 142-149.

97. Kelly, C.R.; Khoruts, A.; Staley, C.; Sadowsky, M.J.; Abd, M.; Alani, M.; Bakow, B.; Curran, P.; McKenney, J.; Tisch, A.; et al. Effect of fecal microbiota transplantation on recurrence in multiply recurrent Clostridium difficile infection: A randomized trial. Ann. Int. Med. 2016, 165, 609-616. [CrossRef] [PubMed]

98. Jiang, Z.D.; Ajami, N.J.; Petrosino, J.F.; Jun, G.; Hanis, C.L.; Shah, M. Randomised clinical trial: Faecal microbiota transplantation for recurrent Clostridum difficile infection-fresh, or frozen, or lyophilised microbiota from a small pool of healthy donors delivered by colonoscopy. Aliment. Pharmacol. Ther. 2017, 45, 899-908. [CrossRef] 
99. Kao, D.; Roach, B.; Silva, M.; Beck, P.; Rioux, K.; Kaplan, G.G.; Chang, H.J.; Coward, S.; Goodman, K.J.; $\mathrm{Xu}, \mathrm{H}$.; et al. Effect of oral capsule- vs colonoscopy-delivered fecal microbiota transplantation on recurrent Clostridium difficile infection: A randomized clinical trial. JAMA 2017, 318, 1985-1993. [CrossRef]

100. Ianiro, G.; Masucci, L.; Quaranta, G.; Simonelli, C.; Lopetuso, L.R.; Sanguinetti, M. Randomised clinical trial: Faecal microbiota transplantation by colonoscopy plus vancomycin for the treatment of severe refractory Clostridium difficile infection-single versus multiple infusions. Aliment. Pharmacol. Ther. 2018, 48, 152-159. [CrossRef]

101. Tan, X.; Johnson, S. Fecal microbiota transplantation (FMT) for C. difficile infection, just say 'No'. Anaerobe 2019, 60, 102092. [CrossRef]

102. U.S. Food and Drug Administration. Fecal Microbiota for Transplantation: Safety Alert-Risk of Serious Adverse Events Likely Due to Transmission of Pathogenic Organisms. Available online: https://www.fda.gov/safety/medical-product-safety-information/fecal-microbiota-transplantationsafety-alert-risk-serious-adverse-events-likely-due-transmission (accessed on 28 September 2020).

103. Aktories, K.; Schwan, C.; Jank, T. Clostridium difficile toxin biology. Ann. Rev. Microbiol. 2017, 71, $281-307$. [CrossRef] [PubMed]

104. Katchar, K.; Taylor, C.P.; Tummala, S.; Chen, X.; Sheikh, J.; Kelly, C.P. Association between IgG2 and IgG3 subclass responses to toxin A and recurrent Clostridium difficile-associated disease. Clin. Gastroenterol. Hepatol. 2007, 5, 707-713. [CrossRef] [PubMed]

105. Kyne, L.; Warny, M.; Qamar, A.; Kelly, C.P. Association between antibody response to toxin A and protection against recurrent Clostridium difficile diarrhoea. Lancet 2001, 357, 189-193. [CrossRef]

106. Kyne, L.; Warny, M.; Qamar, A.; Kelly, C.P. Asymptomatic carriage of Clostridium difficile and serum levels of IgG antibody against toxin A. N. Engl. J. Med. 2000, 342, 390-397. [CrossRef] [PubMed]

107. Leav, B.A.; Blair, B.; Leney, M.; Knauber, M.; Reilly, C.; Lowy, I.; Gerding, D.N.; Kelly, C.P.; Katchar, K.; Baxter, R.; et al. Serum anti-toxin B antibody correlates with protection from recurrent Clostridium difficile infection (CDI). Vaccine 2010, 28, 965-969. [CrossRef] [PubMed]

108. Lowy, I.; Molrine, D.C.; Leav, B.A.; Blair, B.M.; Baxter, R.; Gerding, D.N.; Nichol, G.; Thomas, W.D., Jr.; Leney, M.; Sloan, S.; et al. Treatment with monoclonal antibodies against Clostridium difficile toxins. N. Engl. J. Med. 2010, 362, 197-205. [CrossRef] [PubMed]

109. Steele, J.; Sponseller, J.; Schmidt, D.; Cohen, O.; Tzipori, S. Hyperimmune bovine colostrum for treatment of GI infections: A review and update on Clostridium difficile. Hum. Vaccin Immunother. 2013, 9, 1565-1568. [CrossRef]

110. De Bruyn, G.; Saleh, J.; Workman, D.; Pollak, R.; Elinoff, V.; Fraser, N.J.; Lefebvre, G.; Martens, M.; Mills, R.E.; Nathan, R.; et al. Defining the optimal formulation and schedule of a candidate toxoid vaccine against Clostridium difficile infection: A randomized Phase 2 clinical trial. Vaccine 2016, 34, 2170-2178. [CrossRef]

111. Matsuoka, O.; Patel, D.M.; Sasaki, S.; Oka, H.; Sasaki, T.; Pietrobon, P.J.; Laot, T.; Bouckenooghe, A.; Menezes, J.; de Bruyn, G. Safety and immunogenicity of Clostridium difficile toxoid vaccine in Japanese adults. Hum. Vaccin Immunother. 2018, 14, 322-328. [CrossRef]

112. Sanofi. Sanofi Ends Development of Clostridium Difficile Vaccine. Available online: https://www.sanofi. com/en/media-room/press-releases/2017/2017-2012-2001-2022-2000-2000 (accessed on 3 January 2020).

113. Donald, R.G.K.; Flint, M.; Kalyan, N.; Johnson, E.; Witko, S.E.; Kotash, C.; Zhao, P.; Megati, S.; Yurgelonis, I.; Lee, P.K.; et al. A novel approach to generate a recombinant toxoid vaccine against Clostridium difficile. Microbiology 2013, 159, 1254-1266. [CrossRef]

114. Sheldon, E.; Kitchin, N.; Peng, Y.; Eiden, J.; Gruber, W.; Johnson, E.; Jansen, K.U.; Pride, M.W.; Pedneault, L. A phase 1, placebo-controlled, randomized study of the safety, tolerability, and immunogenicity of a Clostridium difficile vaccine administered with or without aluminum hydroxide in healthy adults. Vaccine 2016, 34, 2082-2091. [CrossRef]

115. Kitchin, N.; Remich, S.A.; Peterson, J.; Peng, Y.; Gruber, W.C.; Jansen, K.U.; Pride, M.W.; Anderson, A.S.; Knirsch, C.; Webber, C. A Phase 2 Study Evaluating the Safety, Tolerability, and Immunogenicity of Two 3-Dose Regimens of a Clostridium difficile Vaccine in Healthy US Adults Aged 65 to 85 Years. Clin. Infect. Dis. 2020, 70, 1-10. [CrossRef]

116. Phetcharaburanin, J.; Hong, H.A.; Colenutt, C.; Bianconi, I.; Sempere, L.; Permpoonpattana, P.; Smith, K.; Dembek, M.; Tan, S.; Brisson, M.C.; et al. The spore-associated protein BclA1 affects the susceptibility of animals to colonization and infection by Clostridium difficile. Mol. Microbiol. 2014, 92, 1025-1038. [CrossRef] 
117. Ghose, C.; Eugenis, I.; Edwards, A.N.; Sun, X.; McBride, S.M.; Ho, D.D. Immunogenicity and protective efficacy of Clostridium difficile spore proteins. Anaerobe 2016, 37, 85-95. [CrossRef] [PubMed]

118. Díaz-González, F.; Milano, M.; Olguin-Araneda, V.; Pizarro-Cerda, J.; Castro-Córdova, P.; Tzeng, S.C.; Maier, C.S.; Sarker, M.R.; Paredes-Sabja, D. Protein composition of the outermost exosporium-like layer of Clostridium difficile 630 spores. J. Proteom. 2015, 123, 1-13. [CrossRef] [PubMed]

119. Barra-Carrasco, J.; Olguín-Araneda, V.; Plaza-Garrido, A.; Miranda-Cárdenas, C.; Cofré-Araneda, G.; Pizarro-Guajardo, M.; Sarker, M.R.; Paredes-Sabja, D. The Clostridium difficile exosporium cysteine (CdeC)-rich protein is required for exosporium morphogenesis and coat assembly. J. Bacteriol. 2013, 195, 3863-3875. [CrossRef]

120. Permpoonpattana, P.; Phetcharaburanin, J.; Mikelsone, A.; Dembek, M.; Tan, S.; Brisson, M.C.; La Ragione, R.; Brisson, A.R.; Fairweather, N.; Hong, H.A.; et al. Functional characterization of Clostridium difficile spore coat proteins. J. Bacteriol. 2013, 195, 1492-1503. [CrossRef]

121. Babcock, G.J.; Broering, T.J.; Hernandez, H.J.; Mandell, R.B.; Donahue, K.; Boatright, N.; Stack, A.M.; Lowy, I.; Graziano, R.; Molrine, D.; et al. Human monoclonal antibodies directed against toxins A and B prevent Clostridium difficile-induced mortality in hamsters. Infect. Immun. 2006, 74, 6339-6347. [CrossRef] [PubMed]

122. Steele, J.; Mukherjee, J.; Parry, N.; Tzipori, S. Antibody against TcdB, but not TcdA, prevents development of gastrointestinal and systemic Clostridium difficile disease. J. Infect. Dis. 2013, 207, 323-330. [CrossRef]

123. Wilcox, M.H.; Gerding, D.N.; Poxton, I.R.; Kelly, C.; Nathan, R.; Birch, T.; Cornely, O.A.; Rahav, G.; Bouza, E.; Lee, C.; et al. Bezlotoxumab for Prevention of Recurrent Clostridium difficile Infection. N. Engl. J. Med. 2017, 376, 305-317. [CrossRef]

124. Johnson, S.; Gerding, D.N. Bezlotoxumab. Clin. Infect. Dis. 2019, 68, 699-704. [CrossRef]

125. Food and Drug Administration. Center for Drug Evaluation and Research Application Number: 761046 Orig1s000 Labeling. Available online: https://www.accessdata.fda.gov/drugsatfda_docs/nda/2016/ 761046Orig1s000Lbl.pdf (accessed on 13 March 2020).

126. European Medicines Agency. Available online: https://www.ema.europa.eu/en/medicines/human/EPAR/ zinplava\#authorisation-details-section (accessed on 13 March 2020).

127. Heidebrecht, H.J.; Weiss, W.J.; Pulse, M.; Lange, A.; Gisch, K.; Kliem, H.; Mann, S.; Pfaffl, M.W.; Kulozik, U.; von Eichel-Streiber, C. Treatment and Prevention of Recurrent Clostridium difficile Infection with Functionalized Bovine Antibody-Enriched Whey in a Hamster Primary Infection Model. Toxins 2019, 11, 98. [CrossRef]

128. Mattila, E.; Anttila, V.J.; Broas, M.; Marttila, H.; Poukka, P.; Kuusisto, K.; Pusa, L.; Sammalkorpi, K.; Dabek, J.; Koivurova, O.P.; et al. A randomized, double-blind study comparing Clostridium difficile immune whey and metronidazole for recurrent Clostridium difficile-associated diarrhoea: Efficacy and safety data of a prematurely interrupted trial. Scand J. Infect. Dis. 2008, 40, 702-708. [CrossRef]

Publisher's Note: MDPI stays neutral with regard to jurisdictional claims in published maps and institutional affiliations.

(C) 2020 by the authors. Licensee MDPI, Basel, Switzerland. This article is an open access article distributed under the terms and conditions of the Creative Commons Attribution (CC BY) license (http://creativecommons.org/licenses/by/4.0/). 